\title{
両側性非復位性関節円板前方転位症例の臨床的検討
}

\author{
瀬古和秀・水谷英樹 - 千賀勝広 \\ 安江一紀・服部 宇・上田実
}

\section{A clinical study of bilateral internal derangement of the temporomandibular joint with closed lock}

\author{
Kazuhide SeKo $\cdot$ Hideki Mizutani $\cdot$ Katsuhiro Senga \\ Kazuki Yasue $\cdot$ Hisashi HatToRI $\cdot$ Minoru UEDA
}

\begin{abstract}
The pathological features of closed lock involving anterior disc displacement without reduction have been elucidated by recent investigations. However, bilateral MRI scans of patients with unilateral TMJ symptoms demonstrated the presence of abnormal findings of the contralateral TMJ disc. Treatment procedures for such cases have yet to be established, and their underlying pathological features are not fully understood.

This study was designed to elucidate the effects of conservative treatment for bilateral closed lock and the correlation between disc configuration, based on MR imaging, and clincal findings.

The following results were obtained:

1. Our non-surgical treatment was successful in $65 \%$ of patients with bilateral closed lock of the TMJ. The efficacy of pumping manipulation of the TMJ with poor mobility (high rigidity on manipulation) in the absence of symptoms was suggested.

2. The disc configuration on MR imaging indicated a high frequency of folding type and non-structured type among symptmatic TMJ and a high frequency of even thickness type among non-symptomatic TMJ.
\end{abstract}

Key words: bilateral (両側性), closed lock (クローズドロック), MRI (磁気共鳴像)

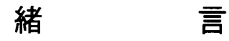

復位を伴わない関節円板前方転位，いわゆるクロー ズドロックの病態1，2）(以下, ADDwoR）は, 近年 明らかになりつつあり, その治療法も保存療法, 外科 療法等, 各種施行され治療成績についても多くの報告 がみられる ${ }^{3-14)}$. しかしながら両側性 ADDwoR は， 片側性症例の中に含まれて扱われることが多く，治療 法についても症状側，つまり片側へのアプローチに言 及したものが多く，両側へのアプローチに言及した報

名古屋大学医学部口腔外科学講座

(主任 : 上田 実教授)

Department of Oral Surgery, Nagoya University

School of Medicine (Chief: Prof. Minoru Ueda)

受付日：平成 7 年 3 月 20 日
告は少ない15 17).

また外山らは，片側にのみ白覚症状を有する患者 112 例の MRI 所見で，無症状側の $47.3 \%$ に関節円板 の前方転位を認めると報告している17)。またわれわれ も日常の臨床の場において症状が片側性であっても比 較的高率に，両側性 ADDwoR が存在することを経験 している。

そこで今回われわれは，両側性 ADDwoR 佂例に対 する保存治療の効果, MRI 所見と保存治療効果との 相関等を明らかにするため臨床的検討を行なった。

\section{対 象}

1993 年 4 月より 1994 年 3 月までに名古屋大学医学 部附属病院歯科口腔外科を受診し，顎関節内障と診 
表 1

\begin{tabular}{|c|c|c|c|c|c|c|}
\hline Pt No & 主訴 & 年齢 & 履病期間 & 初診時の病態 & 治療法 & 治療効果 \\
\hline 1 & 疼痛 & 21 & 10年 & 開口障害型 & “関節穿刺 & 奏効 \\
\hline 2 & 疼痛 & 53 & 25年 & 開口障害型 & 関節穿刺 & 奏効 \\
\hline 3 & 疼痛 & 48 & 20年 & 開口障害型 & 関節穿刺 & 奏効 \\
\hline 4 & 疼痛 & 61 & 14 年 & 開口障害型 & 関節穿刺 & 奏効 \\
\hline 5 & 疼痛 & 53 & 4 年 & 開口障害型 & 関節穿刺 & 奏効 \\
\hline 6 & 疼痛○ & 26 & 10 年 & 開口障害型 & 関節穿刺 & 奏効 \\
\hline 7 & 疼痛 & 58 & 8 年 & 開口障害型 & 関節穿刺 & 奏効 \\
\hline 8 & 疼痛 $\bigcirc$ & 20 & 4 年 & 開口障害型 & 関節穿刺 & 非奏効 \\
\hline 9 & 疼痛 & 41 & 16年 & 開口障害型 & 関節穿刺 & 非奏効 \\
\hline 10 & 開口障害 & 57 & 11年 & 開口障害型 & 関節穿刺 & 非奏効 \\
\hline 11 & 開口障害○ & 22 & 1 年未満 & 開口障害型 & 開口訓練 & 奏効 \\
\hline 12 & 開口障害 & 21 & 10年 & 開口障害型 & Splint 療法 & 奏効 \\
\hline 13 & 疼痛 & 20 & 1 年未満 & 開口障害型 & Splint 療法 & 非奏効 \\
\hline 14 & 疼痛 & 23 & 3 年 & 正常開口型 & 開口訓練 & 奏効 \\
\hline 15 & 疼痛 & 49 & 1 年未満 & 正常開口型 & Splint 療法 & 奏効 \\
\hline 16 & 疼痛 & 25 & 10年 & 正常開口型 & Splint 療法 & 奏効 \\
\hline 17 & 疼痛 & 44 & 6 年 & 正常開口型 & Splint 療法 & 奏効 \\
\hline 18 & 顎運動異常 & 24 & 5 年 & 正常開口型 & Splint 療法 & 非奏効 \\
\hline 19 & 関節雑音○ & 24 & 8 年 & 正常開口型 & Splint 療法 & 非奏効 \\
\hline 20 & 顎運動異常 & 16 & 5 年 & 正常開口型 & Splint 療法 & 非奏効 \\
\hline
\end{tabular}

断された症例のうち MRI 画像診断にて両側性 ADDwoR が確認された, 男性 4 例, 女性 16 例の計 20 例で年齢は 16 歳から 61 歳, 平均年齢 35.3 歳であった.

この 20 例のうち両側に疼痛等の症状を白覚するの は 5 症例のみであった. すなわち 20 例, 40 関節のう ち症状を有する関節が 25 関節，症状を有しない関節 が 15 関節であった。

\section{治 療 方 法}

症例を主訴，現病歴などから開口制限型，および正 常開口型に分類した。すなわち重篤な疼痛, 開口障害 を主症状とし開口域 $35 \mathrm{~mm}$ 以下の泟例を開口制限型, 顎関節部の違和感あるいは, 下顎の運動障害を主症状 とし開口域が $35 \mathrm{~mm}$ をこえる怔例を正常開口型とし た ${ }^{4}$.

今回の症例に対する治療として, 各白の病態, 治療 の必要性の説明, 悪習癖の除去や, 主訴の改善を目的 とした筋訓練，およびマニピュレーション療法 ${ }^{18)}$ は全 症例に施行した。その後, 疼痛や開口障害が重篤な症 例（主として開口制限型）については関節穿刺療法 ${ }^{19)}$ を、下顎運動障害が比較的軽微であり中心位への誘導
が可能な症例（主とし正常開口型）についてはスプリ ント療法20,21)を施行した。なお，関節穿刺療法はパン ピングマニュピレーションを数回施行し, 約 2 か月経 過後, 効果がなかった症例には関節腔洗浄療法を施行 した.

それぞれの症例の主訴, 年齢, 罹病期間, 初診時の 病型，主な治療法，治療効果を表 1 に示す（表 1 ）.

\section{検 討 項 目}

\section{1. 治療効果}

治療に対する効果判定は治療開始 6 か月の時点で,

1) 開口域が $40 \mathrm{~mm}$ 以上であること

2 ) 顎運動の左右均等化

3 ) 前方運動により切端あるいは反対咬合が可能

4 ) 関節痛の消失あるいは軽微化

5 ）日常生活に支障のないこと

の 5 項目のうち 4 以上を示したものを奏効群とし た22).

\section{2. 背景因子の比較}

保存治療奏効群と非奏効群における, 患者が顎関節 になんらかの異常を感じてから当科を初診するまでの 
表 2

\begin{tabular}{ccc}
\hline & 奏効 & 非奏効 \\
\hline 開口障害型 & 9 & 4 \\
正常開口型 & 4 & 3 \\
\hline 計 & 13 & 7 \\
\hline
\end{tabular}

表 3

\begin{tabular}{ccc}
\hline & 奏効 & 非奏効 \\
\hline 罹病期間 & 9.4 年 & 7.2 年 \\
不正咬合 & 6 & 6 \\
悪習癖 & 9 & 5 \\
関節の左右差 & 8 & 4 \\
雑音既往 & 6 & 6 \\
\hline
\end{tabular}

表 4

\begin{tabular}{lcccccc}
\hline & \multicolumn{3}{c}{ 奏効群 } & \multicolumn{3}{c}{ 非奏効群 } \\
\cline { 2 - 7 } & 外側 & 中央 & 内側 & 外側 & 中央 & 内側 \\
\hline concave & 0 & 0 & 0 & 0 & 1 & 1 \\
even thickness & 6 & 6 & 5 & 3 & 1 & 1 \\
convex & 5 & 7 & 7 & 7 & 8 & 6 \\
posterior band enlargement & 2 & 1 & 2 & 0 & 1 & 2 \\
folding & 5 & 5 & 7 & 2 & 2 & 2 \\
none-structuer & 8 & 7 & 5 & 2 & 1 & 2 \\
\hline
\end{tabular}

罹病期間, 不正咬合の有無, 悪習癖の有無, オルソパ ノラマ, シュラー氏変法, 眼窩下顎枝撮影法の, 各 $\mathrm{X}$ 線画像から判断した顎関節の左右差の有無, 同部雑音 既往の有無等の背景因子について比較した。

\section{3 . 関節円板変形度の比較}

関節円板の変形度は, 閉口位矢状面において, 外側, 中央部, 内側の 3 部位にて以下の 6 型に分類し た23〜25).

すなわち,

1 ) 前方肥厚部, および後方肥厚部が明確に確認で きるもの (biconcave)

2 ) 前方肥厚部, 後方肥厚部が明暸でなく扁平なも の (even thickness)

3 ) 扁平ではあるが後方肥厚部がやや厚いもの (posterior band enlargment)

4 ) 前方肥厚部, 後方肥厚部の区別がなく中央部の 厚さが最大のもの (convex)

5 ) 関節円板が折り重なっているもの (folding)

6 ) 関節円板の構造を認めないもの (none-structuer) である.

得られた結果について, 保存治療奏効群と, 非奏効 群との比較, および自覚症状を有する関節 25 関節と, 全く症状を自覚しない 15 関節について比較した。

\section{結}

果

\section{1. 治療効果 (表 2)}

20 症例中, 開口制限群は 13 例, 正常開口群は 7 例
であった。このうち前述の治療効果判定基準に従い保 存治療が奏効したと考えられた症例は, 開口制限群で は 9 例 $(69 \%)$, 正常開口群では 4 例 $(57 \%)$ であった。

\section{2. 背景因子の比較（表 3 ）}

保存治療奏効群と非奏効群における各背景因子は罹 病期間が奏効群では 1 か月から 25 年, 平均 9.4 年, 非 奏効群では 5 か月から 16 年, 平均 7.2 年であった。 た交叉咬合，叢生等の不正咬合は全症例中 12 例 (60\%) に認められた. ANGLE の分類では, ANGLE I 級が 3 例，II 級が 7 例，II 級が 2 例で，そのうち奏 効群では 13 例中 6 例 $(46 \%)$, 非奏効群では 7 例中 6 例 $(86 \%)$ に不正咬合が認められた。同様に片咀嚼, 噌み締め, 食いしばり等の悪習癖をもつ症例が奏効群 では 9 例 $(69 \%)$, 非奏効群では 5 例 $(71 \%)$ に，X 線 による顎関節の左右差を認める症例が奏効群では 8 例 $(62 \%)$, 非奏効群では 4 例（57\%）に，クリックと思 われる関節雑音の既往をもつ症例が奏効群で 6 例 $(46$ $\%)$, 非奏効群では 6 例 $(86 \%)$ に認められた。

\section{3 . 関節円板变形度の比較 (表 4,5 )}

表 4 は保存治療奏効群，および非奏効群における円 板形態の分布を示す。保存治療奏効群では even thickness type が有意に多く, 非奏効群では convex type が有意に多いことが認められた.

表 5 は症状側と非症状側の関節円板形態の分布の比 較を示す. 症状側では folding type, none-structure type が有意に多く, 非症状側では even thickness type が有意に多いことが確認された。 
表 5

\begin{tabular}{lcccccc}
\hline & \multicolumn{3}{c}{ 有症状関節 } & \multicolumn{3}{c}{ 無症状関節 } \\
\cline { 2 - 7 } & 外側 & 中央 & 内側 & 外側 & 中央 & 内側 \\
\hline concave & 0 & 0 & 0 & 0 & 1 & 1 \\
even thickness & 4 & 1 & 0 & 5 & 6 & 6 \\
convex & 5 & 9 & 10 & 7 & 6 & 4 \\
posterior band enlargement & 2 & 2 & 3 & 0 & 0 & 0 \\
folding & 5 & 6 & 7 & 2 & 1 & 2 \\
none-structuer & 9 & 7 & 5 & 1 & 1 & 2 \\
\hline
\end{tabular}

片側施行例 ( 5 症例 5 関節 $)$

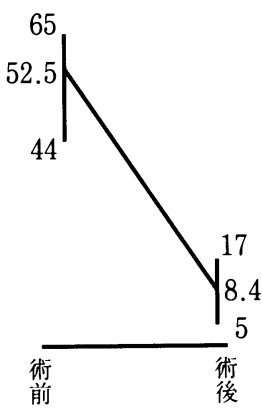

両側施行例 ( 5 症例 10 関節 $)$

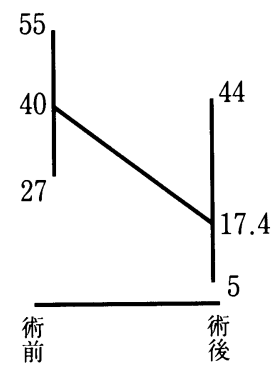

図 関節穿刺療法によるVAS 推移

\section{察}

\section{1. 治療効果}

従来クローズドロック症例に対する保存治療は, 転 位した関節円板の復位を主眼としてきた ${ }^{26)}$. しかし， ロックを解除することは困難であり，たとえ解除が得 られなくても臨床症状の改善は得られるとの報告も多 い22). 今回われわれは, 両側性 ADDwoR 症例に対し てスプリント療法, 関節穿刺療法を中心とした保存療 法を行い 20 例中 13 例 $(65 \%)$ の症例で保存治療が奏 効したと考えられた。この結果は, 瀬上らの $71.8 \%{ }^{27)}$, 戸塚らの $57 \%{ }^{28)}$ ，と大差ないものであった。 また，病 期別にみると開口制限症例では 13 例中 9 例 $(69 \%)$ で 保存治療が奏効した。このうち関節穿刺療法は 10 症 例の主訴側に施行した。しかし，10 症例中 5 症例は治 療効果判定基準を満たさなかった。この 5 症例の共通 した所見として, 非疼痛側 (非主訴側) に一様に関節 可動性の低下がみられた．われわれはこの顎関節の “rigidity（堅さ）”が反対側の hypermobilty 等を惹 起することが疼痛を生じさせる一因ではないかと考え た.すなわち両側性症例においては可動性の不良な関
節を有することにより，むしろ可動性を有する関節に ストレスを強いることになり, 関節円板後部結合組織, 滑膜等に炎症性変化をきたし疼痛を生じさせるのでは ないかと考えた。そこでこの 5 症例に対し非主訴側に も関節の可動性を得る目的で関節穿刺療法を施行した。 この 10 症例の Visual Analog Scale (VAS) の推移 を図に示す. 図からも明らかなように関節穿刺療法に より疼痛は有意に改善し, 両側性 ADDwoR 症例にお いては，たとえ非主訴側であっても関節の可動性が低 下している場合は両側への積極的なアプローチが必要 な事が示唆された. 同様の機序を考えれば, 両側に可 動制限のある症例は疼痛側, 非疼痛側にかかわらず, 両側への関節穿刺療法が有用なことが推定された。

また正常開口症例では 7 例中 4 例 $(57 \%)$ で保存治 療が奏効した。この保存治療非奏効例 3 例は, 初診時 より疼痛もなく，おおむね下顎の可動性も良好で臨床 的にほとんど問題がないように思われたが, 患者自身 の顎関節部に対する不満が強く, 問診等より口腔心身 症的要素の強い症例のように思われた ${ }^{29)}$. 竹之下は CMI と顎関節症の治療成績との間に関連は見られな いと報告している ${ }^{30)}$. 当科でも CMI, Y-G, MAS, SDS 等の各心理テストを実施しているが，いずれも 明確なスクリーニング法とはなっていない。これらス クリーニング法も含めた心身医学的なアプローチの確 立は今後の課題と思われた。

\section{2 . 背景因子}

背景因子の比較において保存治療奏効群と非奏効群 の間に統計学的有意差は認めなかった。

Farrar と McCarty は顎関節内障の概念としてク ローズドロックはクリックより移行するものとして報 告している ${ }^{3)}$. しかし Nitzanらは臨床的観察からか ならずしも Farrarらのいうようなエピソードをもた ない症例も多く見受けられると報告している4).今回 の研究では, 問診からのみの評価であるが, クリック と思われる雑音既往を持たない症例が 8 症例 $(40 \%)$ に認められ，いわゆる間欠的ロックの病態のみを経由 してクローズドロックに陥る症例が比較的高率に存在 
することが確認された。

\section{3 . 関節円板変形度の比較}

森家らは, 顎関節内障の罹病期間と関節円板の変形 度には密接な関係があると報告している ${ }^{10)}$ 。一方，和 嶋らは罹病期間と関節円板の変形の発現には関連が見 いだせないと報告している31). 今回，われわれが検討 を行なった 20 症例においては，関節円板の変形度と 罹病期間との間に関連を見いだすことはできなかった。 しかし保存治療抵抗性の比較において保存治療奏効群 では even thickness type が, 保存治療非奏効群では convex type が有意に多く，また疼痛等症状を有する 関節と無症状の関節との比較では，有症状関節では folding type, none-structuer type が, 無症状関節 では even thickness type が有意に多かった。また関 節穿刺症例 15 関節の治療前後の円板形態の比較にお いては，症状の消失の有無にかかわらず差は認められ なかった。

Scapino は関節円板の変形は, 円板内部のコラーゲ ン線維の変性によるコラーゲン線維の走行パターンの 乱れにより惹起されると述べている32).このことより， われわれはコラーゲン線維の変性の程度が, 円板形態 の決定に影響をおよぼすことにより臨床症状に変化を 現わすのではないかと考えた．しかし，その機序はい まだ明確ではなく，その解明は今後の課題と思われた.

\section{結語}

今回われわれは，両側性非復位性関節円板前方転位 患者 20 例に対し臨床的検討を行なった。 その結果, たとえ疼痛等の症状を有しなくても可動性が不良で, 反対側に症状を有する関節が存在する場合，両側への 関節穿刺療法が有用なことが示唆された。また今回検 討を行なった各背景因子と保存治療に対する抵抗性と の間に関連はみいだせなかった，MRI 画像における 関節円板の形態の比較において保存治療奏効群におい ては even thickness type が非奏効群では convex type が有意に多く, 症状を有する関節では folding type, none-structuer type が, 症状を有しない関節 では even thickness type が有意に多かった。

\section{参 考 文 献}

1) Farrar, W.B., McCarty, W.L.: Inferior joint space arthrography and characteristics of condylar paths in internal derangement of the TMJ. J Prosthet Dent 41: 5485551979

2) Sanchez-Woodworth R.E., Tállents R.H., et al.: Bilateral internal derangement of temporomandibular joint.: Evaluation by magnetic resonance imaging. Oral Surg
Oral Med Oral Pathol 62: 281-285 1988.

3) Farrar, W.B.: Diagnosis and treatment of anterior dislocation of the articular disk. NY J Dent 41: 348-351 1971.

4) Nitzan, D.W., Dolwick, M.F.: An alternative explanation of closed lock symptoms in the internal derangement process. J Oral Maxillofac Surg 49: 810-815 1991.

5) Choi, B.H., Yoo, J.H., et al.: Comparison of magnetic resonance imaging before and after nonsurgical treatment of closed lock. Oral Surg Oral Med Oral Pathol 78: 301-305 1994.

6) Turley, P.K.: Surgical-orthodontic management of presistent closed lock of the TM joint. Angle Orthod 63: 9 -16 1993.

7) Reich, R.H.: Temporomandibular joint surgery. Curr opin Dent 2 : 17-24 1992.

8) McCain, C.L., Sanders, B., et al.: Temporomandibular joint arthroscopy: a 6 year multicenter retorospective study of 4,831 joints. J Oral Maxillofac Surg 50: 926-930 1992.

9) Davis, C.L., Kaminishi, R.M., et al.: Arthoroscopic surgery for treatment of closed lock. J Oral Maxillofac Surg 49: 704-707 1991.

10）森家祥行, 村上賢一郎, 他: 顎関節内障クロー ズドロック症例の臨床病態に関する検討．第 1 報；ロック期間と臨床症状ならびに開口度との 関連について. 日口外誌 36: 1311-1319 1990.

11）森家祥行, 村上賢一郎, 他：顎関節内障クロー ズドロック症例の臨床病態に関する検討．第 2 報; MRI による円板形態と開口度, 臨床症状 について. 日口外誌 36: 2353-2361 1990.

12）高木律男, 上路敬一, 他：クローズドロック症 例（非ロック解除例）における臨床所見の推移 について. 日口外誌 39: 1314-1319 1993.

13）和嶋浩一, 木津真庭, 他：顎関節内障 (closed lock）の保存治療に関する研究. lock 期間と 関節円板変形の関連について。日科誌 37 : 934-943.

14）門脇 繁, 中嶋頼俊, 他 : 復位を伴わない関節 円板の前方転位（クローズドロック）症例の治 療法について. 顎機能訓練と関節鏡視下手術. 日顎誌 $5: 96-1001993$.

15) Hankey, G.T.: Temporomandibular arthrosis. Brit Dent J 97: 249-270 1954.

16）浅田恍一, 野田みどり，他：両側性顎関節症の 臨床統計的観察。日口外誌 36: 2155-2165 1990 .

17）外山正彦, 栗田賢一,他：片側に顎関節症状を 訴えた患者の両側 MR 所見。関節円板前方転 位について. 日顎誌 4:99-108 1992.

18) Farrar, W.B., McCarty, W.L.: A Clinical Outline of Temporomandibular Joint; 
Diagnosis and Treatment. Montgomery Printing Co, Alabama, 1983 p129-130.

19) Nitzan, D.W., Dolwick, M.F., et al.: Temporomandibular joint arthrocentesis: a simplified treatment for sever, limited mouth opening. J Oral Maxillofac Surg 49: 1163-1167 1991.

20) Chung, S.C., Kim, H.S.: The effect of the stabilaization splint on the TMJ closed lock. Cranio 11: 95-101 1993.

21) Clark, G.T.: TMJ repositioning appliance: A technique for construction, insertion and adjustment. J Craniomandib Pract 4 : 37-46 1986.

22）千葉雅俊, 熊谷正浩, 他 : 顎関節クローズドロッ クに対する保存療法の MRIによる評価。日口 外誌 40: 271-277 1993 .

23) Westesson, P. L., Rohlin, M.: Internal derangement related to osteoarthrosis in temporomandibular joint autopsy specimens. Oral Surg Oral Med Oral Pathol 57: 17-22 1984.

24) Heffez, L., Jordan, S.: A classification of temporomandibular joint disk morphology. Oral Surg Oral Med Oral Pathol 67:
11-19 1989.

25）川田雅章 : 顎関節円板の前方転位と形態の変化 : MRIによる解析. 日科誌 43: 343-354 1994.

26）和気裕之,ー木野孔司，他：クローズドロックを 示した顎関節症に対する保存治療の経験.日口 外誌 33: 1677-1683 1987.

27）瀬上夏樹, 村上賢一郎, 他 : 顎関節内障クロー ズドロック症例に対するマニピュレーションな らびにパンピングマニピュレーション療法の評 価. 日口外誌 34: 1123-1131 1988.

28）戸塚靖則, 澤田 明, 他 : 復位を伴わない関節 円板前方転位に対する治療法の検討. 日口外誌 34: 1325-1337 1988.

29）中川哲也 : 心身症への治療的取り組み. 最近の 動向を中心に. 精神科 MOOK 24: 89-99 1989.

30）竹之下康治, : 頇関節症の臨床的観, 転帰 - 治 療成績と諸因子. 日口外誌 24: 1020-1028 1978.

31）和嶋浩一, 三田雅彦, 他: 顎関節内障における 関節円板の形態変化に関する研究．日顎誌 1 : 139-150 1989.

32) Scapino, R.P.: Histpathology assosiated with malposition of the human temporomandibular joint disk. Oral Surg Oral Med Oral Pathol 55: 382-397 1983. 